УДК 371.383.061:378

DOI:

Юлія Колісник-Гуменюк, кандидат педагогічних наук, старший викладач кафедри загальнотехнічних дисциплін і охорони праці відокремленого структурного підрозділу

“Львівський навчально-науковий иентр професійно-технічної освіти”

Національного педагогічного університету імені М.П. Драгоманова, м. Київ

\title{
ДЕФІНІТИВНИЙ АНАЛІЗ ПОНЯТЬ КУЛЬТУРОТВОРЧІСТЬ, КУЛЬТУРОТВОРЧЕ СЕРЕДОВИЩЕ, КУЛЬТУРОТВОРЧА КОМПЕТЕНТНІСТЬ
}

На сучасному етапі розвитку педагогічної науки виняткового значення набувають питання узгодження та уточнення національної та міжнародної термінології. Педагогіка має свій понятійний апарат - систему педагогічних понять, щь виражають наукові узагальнення, відображають педагогічний досвід $і$ знання. 3 огляду на розробленість найбільш розповсюджених педагогічних категорій детально розглянемо лише деякі, найбільш вагомі в площині вдосконалення підготовки майбутніх викладачів професійно-художніх дисциплін, а саме: культуротворчість, культуротворче середовище, культуротворча компетентність.

Ключові слова: освіта; викладач; художньо-педагогічна освіта; культуротворчість; культуротворче середовище; культуротворча компетентність.

Jim. 10.

Yuliya Kolisnyk-Humenyuk, Ph.D.(Pedagogy), Senior Lecturer of the General Technical Disciplines and Labor Protection Department of Separate Structural Unit "Lviv Educational and Scientific Center of Vocational Education" National Mykhaylo Drahomanov Pedagogical University

\section{DEFINITIVE ANALYSIS OF CONCEPTS: CULTURAL CREATION, CULTURE-MAKING ENVIRONMENT, CULTURE-MAKING COMPETENCE}

Human beings, cultivating a culture, creating moral and material values, improve and perfect themselves. Culture itself for human purpose is the most appropriateform of resolving contradictions between spirituality and affability, between spirituality and sociality. Personality cannot exist only in the dimension of one essence - social, vital or spiritual, because only in their combination there is the uniqueness of human existence. The high level of the common culture of society, nation is provided by the proper education and culture level of its members. Any expression of culture is a manifestation of qualitative properties and characteristics, of the degree of human development. The real, living culture is inseparable from a person as a subject of culture, the process of human formation proceeds as a cultural-historical process. Its result is manifested in the form of communication, involvement in present society values, traditions, and the acquisition of the methods and skills that are inherent in this culture. One can say that culture is the world of man, the way of its existence, the process of development of human forces abilities, the measure of the degree of human in man, characteristic of the development of human being.

The development of education as a social institution is influenced by many factors and conditions of the functioning of society, among which one of the most important is the relationship with culture. It is culture that focuses on the system of value representations, which form the basis of the person's landmarks of the subject, regulate its activity, translate the person into a qualitatively different way of being - more meaningful and orderly.

At the present stage of the development of pedagogical science, issues of harmonization and clarification of national and international terminology are becoming of exceptional value. Pedagogy has its conceptual apparatus - a system of pedagogical concepts expressing scientific generalizations, reflecting pedagogical experience and knowledge. Taking into account the development of the most widespread pedagogical categories, we will consider in detail only a few, the most important in the field of improving the training of future teachers of professional and artistic disciplines, namely: cultural creativity, culture-making environment, culture-making competence.

Keywords: an education; a teacher; artistic and pedagogical education; cultural development; culturemaking environment; culture-making competence.

П остановка проблеми. Людина, творячи культуру, створюючи моральні та матеріальні цінності, удосконалює й саму себе. Саме культура $\epsilon$ найбільш відповідною людському призначенню формою вирішення суперечностей між духовністю й привітністю, між духовністю і соціальністю. Особистість не може існувати лише у вимірі однієї сутності - соціальної, вітальної чи духовної, бо саме в їхньому поєднанні полягає унікальність людського існування. Високий рівень загальної культури суспільства, нації забезпечуе належна освіта і культура його членів. Будь-яке вираження культури $€$ проявом якісних 

КУЛЬТУРОТВОРЧАКОМПЕТЕНТНІСТЬ

властивостей та ознак, ступеня розвитку людини. Реальна, жива культура невіддільна від людини як від суб' єкта культури, сам процес формування людини протікає як культурно-історичний процес. Його результат проявляється у формі спілкування, залучення до чинних у суспільстві цінностей, традицій, оволодіння властивим саме цій культурі прийомами і навичками діяльності. Можна сказати, що культура - це світ людини, спосіб їі буття, процес розвитку людських сил і здібностей, показник міри людського в людині, характеристика розвитку людської істоти [5, 17 - 18].

Людина, як суб'єкт культури є духовно самодостатньою особистістю, котра укорінена в національній культурі й здатна до духовного, морального, креативного удосконалення. Самовдосконалення людської особистості нерозривно пов'язане із засвоєнням нею культурних надбань цивілізації. Культура притаманна кожній свідомій групі людей як комплекс специфічних і в певному сенсі нормативних способів і форм соціальної інтеграції, які регулюють поведінку, пізнання, комунікації, оцінку й передачу символами, що існують у навколишньому середовищі, вона є фундаментом для самоідентифікації суспільства й особистості.

В. Семенов виділяє три основні форми прояву людських сил в культурі: по-перше, освоєння культурної реальності, оволодіння накопиченим людством культурним багатством; по-друге, культуростворюючу, культуротворчу діяльність; по-третє, особистісний прояв культури в безпосередньому культурному бутті, тобто реалізацію людиною у всій своїй повсякденній діяльності, у відносинах, в поведінці, в способі життя, в побуті освоєних нею культурних досягнень, знань, умінь, навичок $[8,16]$. У педагогічній діяльності виявляються всі три названі В. Семеновим форми культурної діяльності людини. Місія освіти у процесі культуротворення - переклад соціальної ситуації розвитку дитини у спеціально організовану педагогічну (культуротворчу) ситуацію.

Мета статті детально розглянути найбільш вагомі в площині вдосконалення підготовки майбутніх викладачів професійно-художніх дисциплін понять, а саме: культуротворчість, культуротворче середовище, культуротворча компетентність.

Аналіз останніх досліджень і публікацій. В дослідженні ми спираємось на положення, які знайшли своє відображення в працях А. Асмолова, М. Бахтіна, В. Біблера, Г. Бенток, Дж. Веллей, М. Гріна, О. Гайдамаки, Е. Гуссерля, М. Кагана, Т. Кузьміна, В. Леонтьєва, Л. Масола,
Н. Миропольської, О. Олексюка, О. Отич, О. Ростовського, Г. Сунгатулліна, Г. Філіпчук, О. Щолокова та ін.

Виклад основного матеріалу дослідження. Обгрунтовуючи характеристику поняття культуротворчість зазначимо, що значущими для угочнення цієї дефініції $є$ філософські концепції гуманізму XX ст., в яких культура виступає засобом “конструювання" особистості, “регулятивною ідеєю буття індивіда"; а культуротворчість “спрямовується не тільки зовні, а й внугрішньо - на самопізнання і творення свого “Я”, нових можливостей розуму і волі". Лише в культурному просторі індивідуальність стає “тим, чим вона $є$ в собі, і тільки тоді вона $є$ в собі й має реальне існування; рівень ії культури визначає ступінь іiї реальності та сили" [2, 349].

Творчий потенціал епохи визначається нерозривною єдністю традицій і новацій. Культуротворчість розгортається навколо традиції, бо культура $є$ лише там, де $є$ традиція, водночас вона реалізується навколо екземпліфікації людьми наслідуваних моделей імітативної поведінки, тобто ціннісно-значимих ідеалів культурної діяльності. Особистісне буття людини проявляється в його ментальних ознаках, і водночас як суб'єкта культури, суб'єкта історії, суб' єкта нації, суб'єкта світу.

Е. Гуссерль розглядає історичність як таку константу, що визначається стилем людського існування, в межах якого стиль культуротворчості при піднесенні або стагнації залишається формально тим самим [3, 108]. За Е. Гуссерлем, стиль культуротворчості можна визначити як такий спосіб, прийом, метод, контекст якого збігається зі стилем людського існування. Очевидно, що культуротворчість має глибинні антропологічні основи, які відтворюють еволюцію людини, дають характеристику її етнічних специфікацій.

Культуротворчість передбачає професіоналізм діяльності, відповідні форми та методи їі здійснення, здатність до інновацій. Реалізується культуротворчість як подолання меж можливого, прагнення до досконалості, творення буття засобами культури. Т. Кузьміна розглядає культуротворчість як “єдність пізнавальної і перетворювальної діяльності особистості, що проявляється як в оволодінні культурними смислами, так і у виявленні нових культурних форм, цінностей сенсів, за допомогою інтерпретації, трансформування, оцінки" $[6,65]$.

Натомість О. Жорновапоняття “культуротворення" тлумачить як діяльність, пов’язану із збереження i примноженням культури, тоді як “культуротворчість” 


\section{ДЕФІНІТИВНИЙ АНАЛІЗПОНЯТЬ КУЛЬТУРОТВОРЧІСТЬ, КУЛЬТУРОТВОРЧЕ СЕРЕДОВИЩЕ, КУЛЬТУРОТВОРЧА КОМПЕТЕНТНІСТЬ}

розглядає як розкриття творчого потенціалу особистості. Науковець вживає поняття “культуротворчість" з метою характеристики майбутнього фахівця і визначення його здатності “...творити, звершувати себе як носія та володаря величної культуротворчої сили” [4, 343]. У iї концепції ми знаходимо тлумачення культуротворчості як феномена, функції системи “Соціокультурна цілісність - Культуротворець", універсальну поведінкову модель фахівця в процесі оновлення культурних смислів і характеристики студентів, підготовлених до створення нового узвичній професійній діяльності.

Фундаментальну роботу, в якій безпосередньо розкрито природу, системи, процеси культуротворчості, виконала В. Леонтьєва. У праці “Культуротворчий процес: обгрунтування та начала" вона здійснила послідовну спробу аналізу культуротворчих процесів у вітчизняній і в європейській філософській традиції, втілюючи принцип культуротворчості в розумінні світу та утвердженні особистісного начала як носія смислу в цьому світі. В. Леонтьєва відзначає, що одиницею культуротворчого процесу є культурний акт як утвердження культурного явища (конкретної єдності змісту й культурної форми) [7, 56 - 57]. Дослідниця вважає, що структуру культуротворчого процесу характеризує взаємодія трьох різноякісних типів культурних форм: остенсивних, імперативних, аксіологічних, які співвідносяться з певним рівнем афірмації та наповнюються відповідними культурними смислами. У формуванні історично конкретної структури певного культуротворчого процесу головними постають “міра їі відповідності історичній логіці становлення культурних форм; міра змістовної спадкоємності між досвідом, який транслюється всіма типами культурних форм; міра ціннісної синхронізації різних структурних потоків культурної трансляції, що функціонують одночасно". Такі положення набувають евристичного смислу, особливо в контексті “культуротворчих трансформацій під час переходу до інформаційної цивілізації, у тому числі в Україні”.

Ні викладачі, ні культурний простір не створюють людину, не народжують у неї здатності любити, бути допитливим, філософствувати або творити. Вони надають можливість, створюють сприятливі умови, спонукають, допомагають тому, що існує в самій людині, стати реальним і актуальним.

У культуротворчому середовищі творчі здібності студентів визначаються, як: набуття знань, умінь, навичок, необхідних для самостійного творчого рішення поставлених задач, що виступають на перший план за своєю значущістю згідно з сучасними вимогами; потреба та уміння напрацьовувати нові знання та уміння для вдосконалення професійно-творчої діяльності; прагнення до самореалізації, до втілення у виробничій практиці своїх намірів і способу життя. Творчу атмосферу в колективі створюють: спільні творчі пошуки; визначення пріоритетних напрямів роботи; педагогічний колектив об'єднаний ідеєю виховання громадянина нашої держави; взаємопорозуміння у викладацькому колективі; довіра, взаємоповага, стабільність кадрів, належний психологічний мікроклімат; готовність членів колективу приймати рішення та нести за них відповідальність; прагнення учасників навчальновиховного процесу до саморозвитку, творчості, прояву ініціативи.

Основними напрямами, які сприяють активізації творчого діяльності у культуротворчому середовищі, є: залучення студентів до цінностей культури; створення умов для розвитку молодої людини як суб'єкта культури; допомога студентам у розвитку творчого потенціалу, здібностей, самореалізації у закладі вищої освіти, культуротворчому середовищі, майбутній професії.

Активізація творчої діяльності особистості в культуротворчому середовищі закладу вищої освіти може визначатись за таких умов: 1. Наявність комплексу загальних рис творчої особистості: ерудованості, почуття нового, гнучкості і широти мислення, активності, волі, розвинутого уявлення. 2. Розширення самоосвітніх і самоконтролюючих підходів до пізнання студентами нових знань. 3. Самоаналіз як один з основних умов ефективності процесу організації самостійної роботи у вищій школі.

Професійне навчання майбутніх фахівців художнього профілю спрямовується на розвиток у них світоглядних, моральних, естетичних цінностей, креативності й рефлективності у пізнанні та самостійній діяльності. Вимоги, які стоять перед сучасною вищою художньопедагогічною освітою України, акцентують увагу на діяльності закладу, орієнтуючись на рівень транснаціональної освіти, включення її у світовий полікультурний простір, розвиваючи власне культуротворче середовище. У нашому дослідженні культуротворче середовище 3ВО виступає умовою самореалізації особистості студента в навчальному процесі та розглядається як система життєдіяльності, що включає взаємопов'язану сукупність навчальної та позанавчальної діяльності суб'єктів освітнього 
простору, покликана формувати їхнє культурноосвітнє мислення, актуалізувати ціннісні орієнтації, реалізувати творчий потенціал.

Свідомість людини розвивається в оточенні культурних цінностей, що кристалізують досвід світосприйняття. Реалізація культуротворчих функцій мистецтва потребує спеціальної педагогічної роботи, спрямованої на прилучення студентів до художньої культури, формування їх творчих здібностей, створення культуротворчого середовища, яке базується на гуманістичних, демократичних цінностях й створює умови для розвитку культурсуб' єктного процесу освіти на основі актуалізації професійно-творчої діяльності для саморозвитку, самовизначення i самореалізації особистості. Культуротворче середовище стає умовою гуманістичної освіти, яка формує інтелігентність особистості в орієнтації на культурні традиції та духовні цінності.

Сутність культуротворчого середовища закладу вищої освіти виявляється у тому, що воно відображає ідеї та цінності сучасної постіндустріальної парадигми освіти, включає в себе процеси розвитку і саморозвитку базової культури особистості, педагогічної культури викладача, відображає особливості їх взаємодії. У зв'язкуз цим, розроблення науково-педагогічної концепції формування культуротворчого середовища у закладі відповідає суттєвим потребам сучасної освіти, яка розвивається на основі ідей демократії та гуманізму.

У трактуванні поняття культуротворча компетентність особистості акцент робиться на готовності особистості до культурного самовизначення, яке пов'язане 3 постійним вибором різних форм культурної активності.

Передусім стисло розглянемо сутність поняття “компетентність”. Вперше поняття “компетенція”, “ключові компетенціі” розпочали використовувати в США в сфері бізнесу в 70-х роках минулого століття, що було пов'язано 3 проблемою визначення якостей майбутнього співробітника, які повинні впливати на успішність його професійної діяльності; ці якості називалися компетенціями. Основою цієї концепції була праця відомого американського психолога Р. Уайта “Перегляд поняття мотивації: концепція компетентності” (1959 р.). Це дослідження стало першою працею в сфері теорії компетентності, у якій в мотиваційно-психологічному контексті визначено компетентність як ефективну взаємодію індивіда $з$ довкіллям навколо нього, як первісну та найсильнішу рушійну силу особистості.

В Свропі термін “компетенція” був запроваджений у 1971 р. німецьким педагогом
Г. Ротом, який вперше презентував компетентнісну модель $[10,36]$. Розробляючи цю модель, учений визначив вихідну точку педагогічного впливу на мотиваційну і рушійну поведінку дітей: "Усі живі істоти мотивовані від природи (компетенціi), щоб ефективно керувати середовищем". Г. Рот виділив чотири послідовні періоди людської діяльності, які пов'язані з формуванням і розвитком компетенцій: опанування рухової діяльності, розвиток ділової компетенції, розвиток соціальної компетенції, розвиток особистої компетенції.

Доречно зазначити, що закордоном існують різні підходи до трактування поняття “компетентність”. Зокрема, в межах американського підходу компетентність розглядають як характеристики індивіда для компетентного виконання професійної діяльності. Британській підхід базується на властивостях самої діяльності. Науковці Д. Ерпенбек і X. Фолькер зазначають, що компетентність - це диспозиція самоорганізації в управлінні набутими й новими знаннями у неординарних ситуаціях, розглядають професіоналізм фахівця як високий рівень самоорганізованої діяльності на основі особистісної, предметно-методичної, соціальнокомунікативної компетентностей. Галузеві стандарти вищої освіти (ГСВО) зазначають, компетенція “включає знання й розуміння (теоретичне знання академічної області, здатність знати і розуміти), знання як діяти (практичне й оперативне застосування знань до конкретних ситуацій), знання як бути (цінності як невід'ємна частина способу сприйняття й життя з іншими в соціальному контексті), а також предметна область, у якій індивід добре обізнаний і проявляє готовність до виконання діяльності".

Л. Масол і О. Гайдамака стверджують, що лише художня компетентність яка виступає, як досвідченість особистості в царині мистецтва, здатність до самоорганізації в мистецькій діяльності на основі ціннісних естетичних орієнтацій, допомагає митцю в розвитку власного художньо-творчого потенціалу. На думку вчених, це поняття має особистісно-діяльнісний та інтегративний характер, оскільки є багатогранним показником результативності мистецької освіти і самоосвіти, що інтегрує всі компоненти: змістовий (знання), процесуальний (уміння), аксіологічний (цінності, орієнтації), самореалізаційний (активність, самостійність), креативний (творчість).

Науковці, які займаються проблемою культуротворчості, як правило, ведуть дослідження в таких аспектах: культуротворче 


\section{ДЕФІНІТИВНИЙ АНАЛІЗПОНЯТЬ КУЛЬТУРОТВОРЧІСТЬ, КУЛЬТУРОТВОРЧЕ СЕРЕДОВИЩЕ, КУЛЬТУРОТВОРЧА КОМПЕТЕНТНІСТЬ}

виховання, культуротворчі ситуації, культуротворчі цінності, культуротворче середовище. Лише деякі вчені розглядають результат цього процесу, виражений в досвіді творчої діяльності особистості, тобто в компетентностях. Так Г. Сунгатулліна визначає культуротворчу компетентність студента як “сукупність особистісних якостей, які сприяють ціннісному самовизначенню особистості в культурі та її участі в культурогенезі" $[9,11]$. Н. Крилова уточнила дефініцію “культуротворча компетентність” як інтегральну якість особистості, яка визначається готовністю до культуроусвідомлення і культуроспоглядання на основі розширюється сфери пізнання культурно-історичних реалій, норм культури, вираз ціннісно-смислового розуміння культурного самовизначення і наявного досвіду культуротворчості $[1,68]$.

Формування культуротворчої компетенції майбутнього фахівця - це багатоаспектна проблема, що має актуальне соціальне та наукове значення, залежить від багатьох чинників та потребує детального вивчення. Ефективність роботи в цьому напрямі має бути забезпечена всією логікою побудови змісту навчального процесу, стилем навчання та виховання, відповідними організаційними формами i прийомами. Від того, як викладач і студент будуть враховувати їх у своїй діяльності, залежить рівень сформованості культуротворчої компетенції майбутніх викладачів професійно-художніх дисциплін.

Висновки. Констатуємо, що проблема формування культуротворчої компетентності майбутніх викладачів професійно-художніх дисциплін у 3ВО надзвичайно актуальна та зумовлена завданням підготовки інтелектуальних, творчих і духовно розвинених культурних людей, готових ухвалювати відповідальні рішення, усвідомлювати себе громадянином і творцем власного життя. Заклади вищої освіти художнього профілю мають формувати готовність студентів до культуросприйняття, культуроусвідомлення та культуровтілення шляхом їх впровадженню в навчально-пізнавальну, художньо-продуктивну та самоосвітню діяльність.

\section{ЛІТЕРАТУРА}

1. Антропологический, деятельностный и культурологический подходы: тезаурус / ред. Н. Крылова. Москва. Новые иенности образования. Вып. 5 (24). 2005. 183 с.

2. Гегель Г.В. Феноменологія духу. Київ, 2004. $548 \mathrm{c}$.

3. Гуссерль Э. Кризис европейского человечества и философия. Вопросы философии. 1986. № 3. С. 101-116.

4. Жорнова O.I. Теоретико-методологічні засади формування культуротворчості студентів університетів: дис. ... д-ра пед. наук: 13.00.04. Тернопіль, 2007. 395 с.

5. Колісник-Гуменюк Ю.І. Формування професійно-етичної культури майбутніх фахівців у процесі гуманітарної підготовки в медичних коледжах : монографія. Львів, 2013. 296 с.

6. Кузьмина Т. Культуротворческая среда как фактор саморазвития педагогического коллектива образовательного учреждения: дис....канд. пед. наук:13.00.01. Тобольск, 2002. $213 \mathrm{c}$.

7. Леонтьева В.Н. Культуротворческий процесс: основания и начала. Харьков, 2003. 216 с.

8. Семенов В.С. Культура и развитие человека. Вопросы философии. 1982. № 4. С. 15-29.

9. Сунгатуллина Г.И. Развитие культуротворческих компетенций учащихся в условиях создания учебного музея: автореф. дис. ... канд. пед. наук. Казань, 2006. 26 с.

10. Fölsch T. Kompetenzentwicklung und Demografie: Dissertation zur Erlangung des akademischen Grades eines Doktors der Wirtschaftsund Sozialwissenschaften (Dr. rer. pol.). Kassel university press $\mathrm{GmbH}, 2010.146 \mathrm{~s}$.

\section{REFERENCES}

1.Antropologicheskij, dejatelnostnyj i kulturologicheskij podhody: tezaurus (2005). [Anthropological, activity and cultural approach: thesaurus]. (Ed.). N.Krylov. Moscov, New values of education. Issue. 5 (24). 183 p. [in Russian].

2. Hegel, G.W. (2004). Fenomenolohiia dukhu [The Phenomenology of Spirit]. Kyiv, 548 p. [in Ukrainian].

3. Husserl, E. (1986). Krizis evropejskogo chelovechestva i filosofija [The crisis of European humanity and philosophy]. Philosophy issues. No. 3, pp. 101-116. [in Russian].

4. Zhornova, O.I. (2007). Teoretyko-metodolohichni zasady formuvannia kulturotvorchosti studentiv universytetiv [Theoretical and methodological principles of formation of cultural development of university students]. Doctor's thesis. Ternopil, 395 p. [in Ukrainian].

5. Kolisnyk-Humeniuk, Yu.I. (2013). Formuvannia profesiino-etychnoi kultury maibutnikh fakhivtsiv u protsesi humanitarnoi pidhotovky $v$ medychnykh koledzhakh [Formation of professional and ethical culture of future specialists in the process of humanitarian training in medical colleges]. Lviv, 296 p. [in Ukrainian]. 
6. Kuzmina, T. (2002). Kulturotvorcheskaja sreda kak faktor samorazvitija pedagogicheskogo kollektiva obrazovatelnogo uchrezhdenija [Culture environment as a factor of self-development of the teaching staff of an educational institution]. Candidate's thesis. 213 p. [in Russian].

7. Leonteva V.N. (2003). Kulturotvorcheskij process : osnovanija $i$ nachala [Cultural making process: the foundations and beginnings]. Kharkov, 216 p. [in Russian].

8. Semyonov, V.S. (1982). Kultura i razvitie cheloveka [Culture and human development]. Questions of philosophy. No.4, pp. 15-29. [in Russian].
9. Sungatullina, G.I. (2006). Razvitie kulturotvorcheskih kompetencij uchashhihsja v uslovijah sozdanija uchebnogo muzeja [The development of culture-making competence of students in the conditions of creation an educational museum]. Extended abstract of candidate's thesis. 26 p. [in Russian].

10. Fölsch, T. (2010). Kompetenzentwicklung und Demografie [Competence development and demography]. Dissertation on obtaining the academic degree of Doctor of Economics and Social Sciences (Dr. rer. Pol.). Kassel university press $\mathrm{GmbH}, 146$ p. [in German].

Стаття надійшла до редакції 15.04.2019

УДК 373.5.015.31:34

DOI:

Мар'яна Кащук, кандидат педагогічних наук доцент кафедри іноземних мов та культури фахового мовлення Львівського державного університету внутрішніх справ

\section{ФОРМИ ПРАВОВОГО ВИХОВАННЯ УЧНІВСЬКОЇ МОЛОДІ (історичний аспект)}

У статті розглянуто форми реалізації правового виховання старшокласників у другій половині ХX століття. Розкрито суть різноманітних форм правового виховання і охарактеризовано методику їх використання у діяльності загальноосвітньої школи у другій половині ХХ століття. Акиентовано увагу на таких формах правового виховання, як лекторії, кінолекторії, семінари, диспути, вечори запитань та відповідей, тематичні вечори тощч.

Ключові слова: форми правового виховання; старшокласники; лекторії; кінолекторії; семінари; диспути; вечори запитань та відповідей; тематичні вечори.

Jim. 7.

Maryana Kashchuk, Ph.D.(Pedagogy), Associate Professor of the Foreign Languages and Culture of Professional Speech Department Lviv State University of Internal Affairs

\section{FORMS OF LEGAL EDUCATION OF PUPILS (historical aspect)}

The forms of realization of legal education of senior pupils in the second half of the twentieth century are considered in the article. The essence of different forms of legal education is revealed and the methods of their application in the activity of secondary school are characterized. A special attention is paid to such forms of legal education as a cycle of lectures, a cycle of films, seminars, disputes, the evenings of questions and answers, topical evenings, etc. It is stated that the usage of a cycle of lectures as well as a cycle of films has become a necessary condition for successful realization of legal education increasing the level of motivation among pupils. They have been carried out according to a definite plan and organized due to the interests of senior pupils. Seminars and disputes have played an important role in spreading the legal knowledge. Such forms of legal education helped the pupils to exchange their knowledge in the field of law with each other. The evenings of questions and answers as well as topical evenings have contributed greatly to formation of legal culture of senior pupils. An excursion to different places was also an effective extracurricular form of legal education of senior pupils in the course of which they could apply their theoretical knowledge to practice. During such excursions the senior pupils studied the work of state bodies, enterprises, etc and learned how to satisfy physical and spiritual needs of the citizens. Furthermore, some special circles have been formed in many schools, and experienced lawyers carried out seminars and lectures, organized discussion of urgent issues, demonstrated some films pertaining to legal problems, etc. In their turn, the senior pupils worked on their reports, helped law enforcement workers with problematic pupils, 